Gazi University
Journal of Science
http://dergipark.gov.tr/gujs

\title{
Energy Management with Intelligent Plug and Socket
}

\author{
Suleyman Hilmi YILMAZ (i) , Edip TASKESEN* (i), Khandan ROSHANAEI ${ }^{(0)}$, \\ Mehmet OZKAYMAK \\ Department of Energy Systems Engineering, Faculty of Technology, Karabük University, 78050, Karabük, Turkey
}

\section{Highlights}

- This paper focuses on classification process for energy management in electricity field.

- A approach is proposed for classification plug and socket in the study.

- In the study, information was given about electricity consumption.

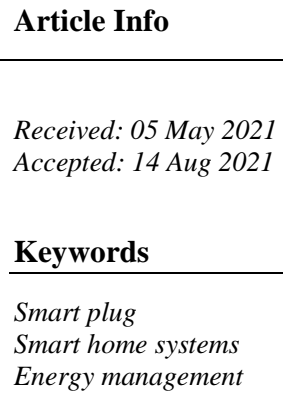

\section{INTRODUCTION}

The energy source usage has varied depending on the changing life conditions of the existence of humanity to the present. Especially with the Industrial Revolution, the increase in production and consumption and the phenomenon of growth has become an important target for economies, which has led to more use of energy resources in the production process and so energy consumption associated with growth. This situation has led to an escalation increase in the studies developed on the subject, and the relationship between energy consumption and growth has often been discussed from the perspective of electrical energy. Electricity consumption contributes significantly to the growth process as it has a wide area of usage in the production process and both as a single or complement of labor and capital factors. The relationship between electricity consumption and growth is important in terms of energy policies [1].

Using electrical energy to power devices all over the world, we use electrical energy in the fields of heating, cooling, communication, transportation and all kind of technological devices. With the produced electrical energy plug and socket systems, people can easily use the electrical power in various places. Plugs are such tools that are used to take electricity from sockets.

The industry has a great role in the development of countries, and industrial activities have progressed without slowing from the past to the present. Countries that keep pace with this development have expanded their treasures by processing cheap raw materials and selling them for high wages [2]. Electric energy, as the single-time tariff and multiple times in Turkey, offers people two different tariffs. The single-time tariff provides sole unit tariff price, and multiple tariffs offer three different unit prices for the consumers and 
people who live in Turkey. While electricity is more expensive at certain times of the day depending on the intensity of use and it is cheaper at certain times in Turkey.

Turkey take place in the line of developing countries [3]. In developing countries, adequate and quality, energy supply has significant share in economic growth. Continuous increase in energy need also increases investments in this field, planning activities, and trade [4]. Electrical energy is important not only for developing countries, but also for all countries of the world. Urbanization is increasing in every country of the world. The acceleration in urbanization in all societies, intensification of migration from rural areas to cities that have entered the process of the metropolitan nation, along with the economic growth of countries, has increased the areas of warming, enlightenment, cooling, transportation, and the use of manufactured goods. This has increased the energy needs of developing countries as well as developed countries and their electricity consumption demands [5].

A significant portion of electrical energy is consumed in residences, workplaces, and public buildings in Turkey. There are approximately 20 million dwellings in Turkey. Considering these data, energy-efficient use of electrical household appliances plays great importance in this case [6-7].

Turkey is an industrializing country. The high population growth rate increases the energy need rapidly in parallel with the increase in energy consumption. Approximately $70 \%$ of the energy used in Turkey is supplied through import path. Therefore, increasing energy efficiency will reduce Turkey's dependence on foreign energy [8].

Consumers can save considerable amounts of money, optionally by delaying or advancing the usage of electricity of some electronic devices. The consumer could save money easier than in the past regards the amount of electricity consumption also the unifying power of electricity usage because of the currency used by the electronic device. RFID (Radio Frequency Identification) technology and smart plug systems were used in this study to give.

Gans and colleagues to provide better information and feedback for consumption, suggest combining the other traditional policy tools such as economic incentives, pricing, and regulation, to assist the improving energy efficiency in the residential sector [9]. Therefore, if the user knows his consumption and the price and cost of the consumption of the electrical device, it will be easier to save financially. Increased transparency in energy consumption can encourage private consumers to energy saving [10].

The aim of this study is to provide information on the electricity consumption of each device which is separate that could be recognized by all kinds of electrical devices to monitor the electricity consumption of all devices used when electricity is cheap. The electrics are used in homes, industrial establishments, public institutions, and organizations as well as everywhere where electricity consumption is realized. In this way, by knowing the consumption values transparently by the user, it creates a plug-socket system that encourages the consumer to save.

Besides, in the usage's area, a new structure will be obtained that does not allow using of devices that are not defined. Additionally, another aim of this work is to create a system that allows industrial enterprises to monitor the electricity consumption amount of all machine groups and clarify the consumption expenditure of the production cost.

\section{MATERIAL METHOD}

RFID technology, which is used in the sense of radio frequency identification, can be used in many areas [11]. With RFID technology, the RFID tag is the system consisting of the chip, antenna, and protective film on which the defined information is stored. RFID technology is nowadays used in mobile phones, tablets and is significantly used in various electrical appliances. In the experimental studies of the research, to provide product-based energy management, firstly, the RFID tag with an identity card was placed on the receipt. In this way, information was obtained about the plug that consumes electricity, hence the electronic device. 
Figure 1 shows an RFID tag in the receipt. The RFID tag is embedded in the receipt. There is a tag reader in the socket. The label reader reads the label and gives the information of which receipt to which device belongs.

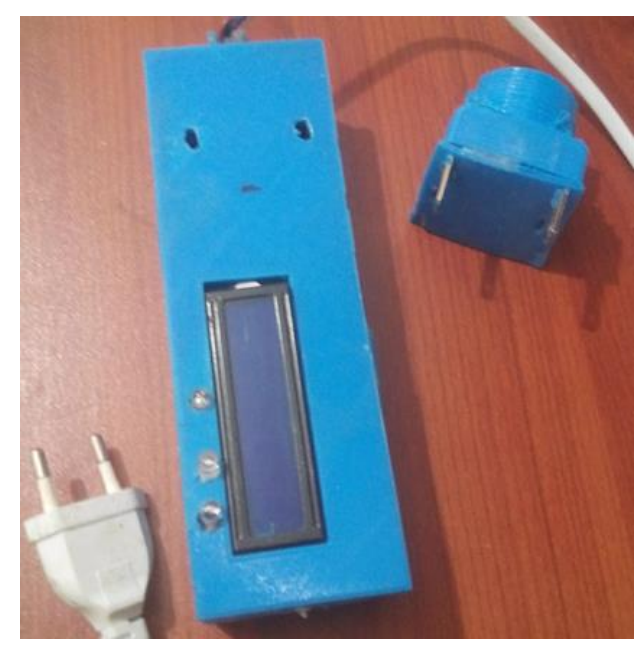

Figure 1. Plug and socket produced by $3 D$ printer

After the device recognition process has been completed, the current sensor embedded in the socket will read how much power the plug, the electronic device draws. The power values to be read as instantaneous data have taken from the micro-USB channel to the socket. Apart from micro-USB, the values to be read by the Wi-Fi Module can be sent to the host computer (Figure 2).

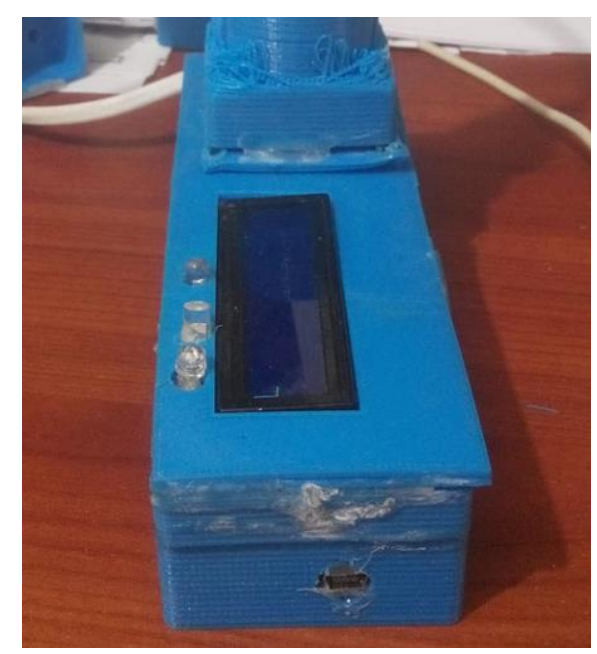

Figure 2. Side view of the smart plug

The label is positioned inside the plug; Label Reader is positioned inside the socket. The purpose of the label and tag reader in the study is to read the ID recognition on the receipt. A label printer identifies the label. For example; apple iPhone 1164 GB chargers, Philips Azure Vacuum Cleaner, etc. after the recognition process, the power is drawn by the electrical device from the network will be drawn (Figure 3). 


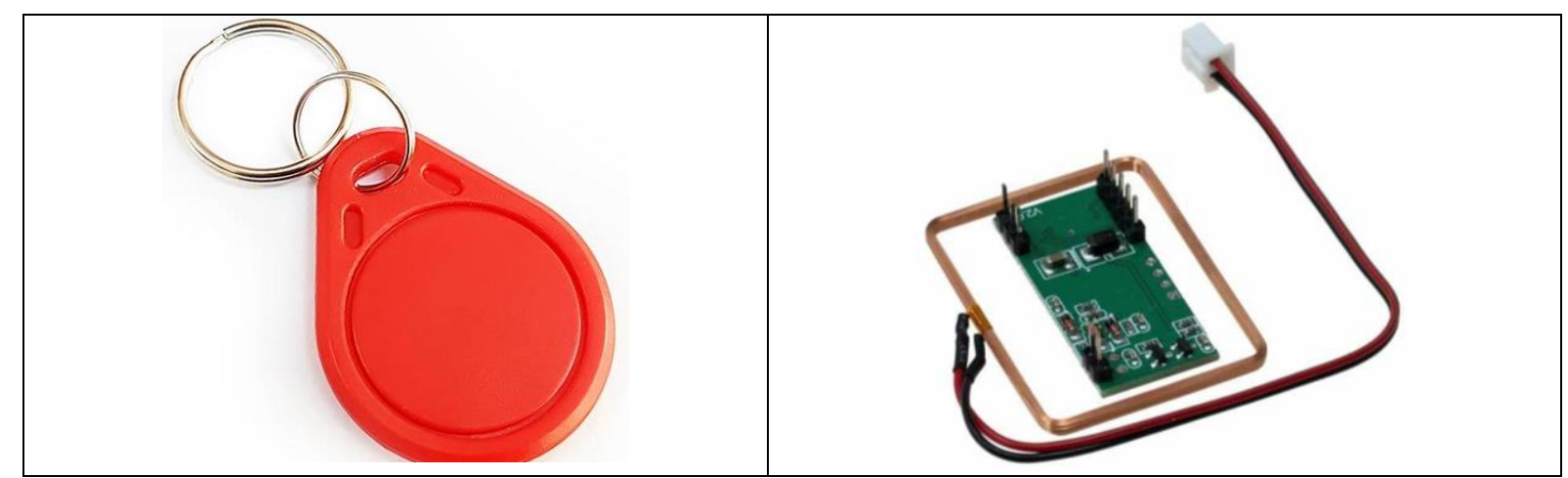

Figure 3. Label and tag protector used in smart prized

With the smart plug and socket, both device recognition process is performed and the consumption values of the device are read. After reading the consumption values, the values of the wired or wireless system are processed, converted, written and shaped into single-time, hourly, daily, and monthly tables.

Table 1 demonstrates the monthly consumption values of a normal dwelling. While calculating the consumption values, the current electricity prices of December-2020 were taken as the basis.

Current prices for the December 2020 are as follows:

- $\quad$ Day Time: $0,652238 \mathrm{TRY} / \mathrm{kWh}$,

- $\quad$ Peak Time: 0,949665 TRY/kWh,

- $\quad$ Night Time: 0,414387 TRY/kWh.

Table 1. Template calculation

\begin{tabular}{|c|c|c|c|c|c|c|c|}
\hline Product's name & $\begin{array}{l}\text { Consumption } \\
\text { (w) }\end{array}$ & $\begin{array}{l}\text { Usage } \\
\text { time } \\
\text { (Hours) }\end{array}$ & $\begin{array}{l}\text { Monthly } \\
\text { usage } \\
\text { time } \\
\text { (Times) }\end{array}$ & $\begin{array}{c}\text { Monthly } \\
\text { Consump } \\
\text { tion } \\
(\mathbf{k W h})\end{array}$ & $\begin{array}{c}\text { Monthly } \\
\text { consumptio } \\
\text { n daytime } \\
(06: 00- \\
17: 00)\end{array}$ & $\begin{array}{c}\text { Monthly } \\
\text { consumption } \\
\text { peak }(17: 00- \\
22: 00)\end{array}$ & $\begin{array}{c}\text { Monthly } \\
\text { consumption } \\
\text { nighttime } \\
(22: 00- \\
\mathbf{0 6 : 0 0 )}\end{array}$ \\
\hline 49 inch LED TV A+ & 100 & 5,00 & 30 & 15 & 9,78 TRY & 14,24 TRY & 6,22 TRY \\
\hline Washing machine A+ & 300 & 2,50 & 10 & 8 & 4,89 TRY & 7,12 TRY & 3,11 TRY \\
\hline Vacuum cleaner & 1200 & 1,00 & 10 & 12 & 7,83 TRY & $11,40 \mathrm{TRY}$ & 4,97 TRY \\
\hline Dish washer A+ & 500 & 2,00 & 30 & 30 & 19,57 TRY & 28,49 TRY & 12,43 TRY \\
\hline Iron & 3000 & 1,00 & 4 & 12 & 7,83 TRY & 11,40 TRY & 4,97 TRY \\
\hline Hair dryer & 2200 & $\mathbf{0 , 2 0}$ & 20 & 0 & 5,74 TRY & 8,36 TRY & 3,65 TRY \\
\hline Oven & 2500 & 1 & & 2 & & $\mathbf{Y}$ & RY \\
\hline laker & 2200 & 0,20 & 30 & 13 & & RY & 5,47 TRY \\
\hline Toast Machine & 2000 & 0,20 & 10 & 4 & 2,6 & 3,80 TRY & 1,66 TRY \\
\hline Total & & & & & 83,16 TRY & 121,08 TRY & 52,83 TRY \\
\hline
\end{tabular}

Table 2 demonstrates the ratio of electrical household appliances to total consumption. $n$ particular, the cost can be reduced by ensuring that household appliances such as heaters, dryers, dishwashers and washing machines, which are used at the user's discretion, operate outside the peak period. 
Table 2. Consumption of electrical appliances [12]

\begin{tabular}{|c|c|}
\hline Product name & Ratio of total consumption(\%) \\
\hline Refrigerator and freezer & 30 \\
\hline Other & 26 \\
\hline Lighting & 12 \\
\hline TV & 9 \\
\hline Heaters & 9 \\
\hline Dryer & 7 \\
\hline Dishwasher & 4 \\
\hline Washing machine & 3 \\
\hline
\end{tabular}

Table 2 shows the comparison of electricity consumption of electrical household appliances according to day, peak and night tariffs. When electrical appliances are not used during the peak period, the user can save $20-25 \%$ of energy.

Table 3. Comparison of Products According to Multi-Time Tariff [12]

\begin{tabular}{|l|c|c|c|}
\hline \multicolumn{4}{|c|}{ Monthly energy consumption } \\
\hline & $\begin{array}{c}\text { Day } \\
(\mathrm{kWh})\end{array}$ & $\begin{array}{c}\text { Peak } \\
(\mathrm{kWh})\end{array}$ & $\begin{array}{c}\text { Night } \\
(\mathrm{kWh})\end{array}$ \\
\hline Donthly Energy Consumption for Standard Products $(\mathrm{kWh})$ & 21,8 \\
\hline Refrigerator & 0 & 0 & 11,376 \\
\hline Washing Machine & 15,68 & 7,11 & 14,25 \\
\hline Oven & 0 & 0 & 58 \\
\hline TV set & 0 & 0 & 2,34 \\
\hline Lighting & 0 & 7,02 & 13,44 \\
\hline Vacuum cleaner & 0 & 20,16 & 0 \\
\hline Iron & 36 & 0 & 9,6 \\
\hline Kitchen hood & 0 & 0 & 0 \\
\hline Computer & 4,05 & 0 & 5,4 \\
\hline Blender & 0 & 0 & 0 \\
\hline Kettle & 0,825 & 0 & 0,73 \\
\hline Hair dryer & 0,73 & 0,73 & 141,136 \\
\hline Total energy consumption $(\mathrm{kWh})$ & 0 & 0 & \\
\hline
\end{tabular}

The values read by the smart plug socket system calculated by a software and programming language algorithm by the name of "JavaScript". Monthly consumption values have been calculated with the software.

The socket that used in this study was produced with a three-dimensional printer, that it could be inserted into the RFID tag reader socket. Further, the tag reader is commercially available. Again, a threedimensional printer produces the receipt so that RFID tags can be inserted and the tag is positioned inside.

The purpose of the smart plug socket is to identify the device. In this way, when different devices are used on the same socket, it will be detected and the consumption values will be calculated. A current sensor is located inside the socket for consumption values. However, consumption values could not be taken from the socket as instant data. Besides, if identification standard due to international norms is determined based on the type of devices used on the plugs, it will be easier to determine the device types. In this case, it may be possible to give electricity or control it in public institutions or various institutions where the use of some devices is prohibited.

The purpose of the smart plug socket is to identify the device. In this way, when different devices are used on the same socket, it will be detected and the consumption values will be calculated. A current sensor is 
located inside the socket for consumption values. However, consumption values could not be taken from the socket as instant data.

The sockets that facilitate the remote or wired management of electrical devices and provide information to the user about consumption values are called smart plugs. There are many smart sockets on the market with various features that are sold at reasonable prices (Figure 4).

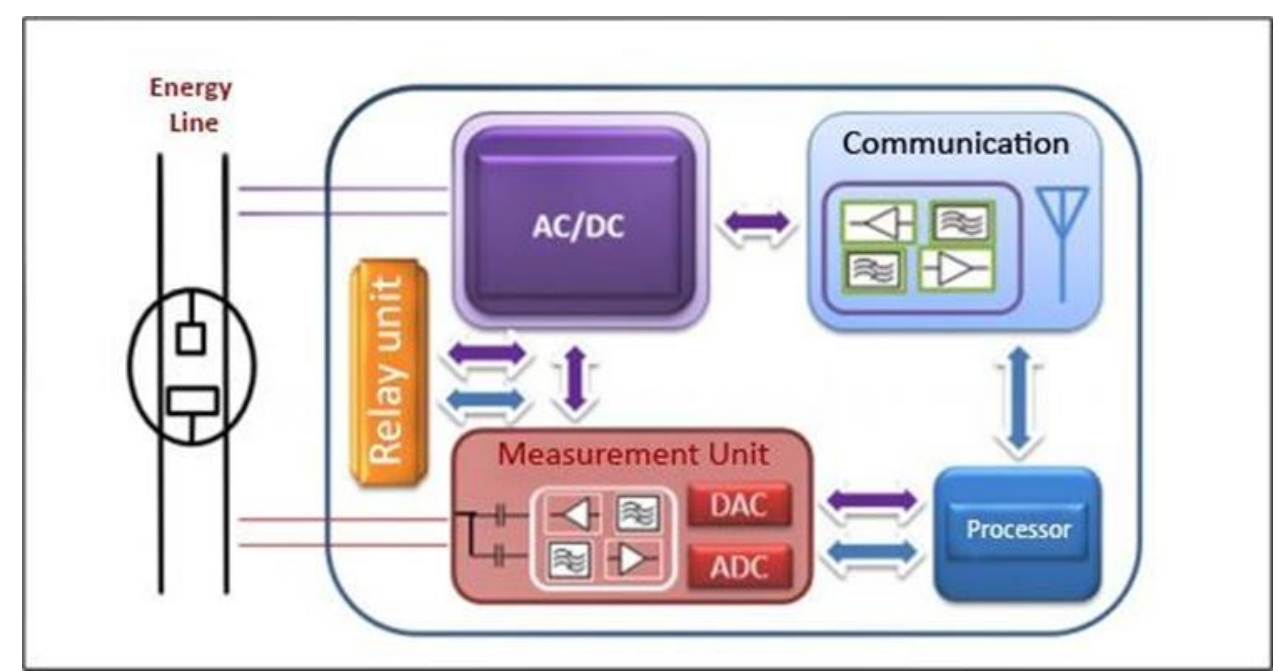

Figure 4. The general structure of the smart plug [13]

The consumption values of the electronic device were drawn with the smart plug and the consumption data was consequently obtained and entered manually. Calculation converted into Turkish Lira the research has done in Turkey the country currency is Turkish Lira.

The main purpose at this stage is to access the monthly total values of the consumption data based on the device and determine the amount of selected device usage at time intervals. Thus, the user will be able to know the amount of monthly electricity bill prices as total and additionally as details for each device. By using this method while a user who uses a multi-time tariff can save money as an arbitrary not mandatory by using optional devices, according to the timetable of the electricity prices and the electricity cheapest time.

Using devices with high electricity consumption, such as washing machines, can make savings dishwashers, andirons, which the user can use whenever he wants. However, since the user identifies the saving amount in the monthly bill, leads to paying much attention to using the devices and consumption. Therefore, the user should be warned while using the devices.

The total power drawn by the device during the usage could be converted into $\mathrm{kWh}$, multiplied over the unit price; furthermore, the consumption values can be calculated. For example; the smart plug is inserted into the washing machine and the consumption-based value is obtained. The washing machine, which worked for about two hours, drew $0.652 \mathrm{kWh}$ of power from the network. This consumption value obtained by multiplying the unit prices, according to the tariff.

The subject of work shifts to electricity consumption to hours when electricity is cheap, by placing a card or by software for electronic devices with the smart plug socket system. Many products on the market have been researched, but due to our research, no API-supported smart plug has been found. With the API support that is attached to the device, it is possible to reach the instantaneous consumption data of the electronic equipment. With instant access, our algorithm besides can retrieve data autonomously, consumption values can be calculated. 
Housing accounts nearly for a fifth of global energy consumption [14]. Consequently, the energy efficiency of the residential market becomes an important target for policymakers and a promising tool for those wishing to comply with the Kyoto protocol [15]. The electrical energy used in homes presented to the user through sockets. Also, when the energy required, energy has drawn from the network by inserting the plug of the electrical device into the socket.

\section{THE RESEARCH FINDINGS AND DISCUSSION}

Energy Market Regulatory three separate tariffs in electricity prices in Turkey and had applied by the Authority. These separate tariffs are day, peak, and night tariffs. However, end-users of electricity in Turkey are sold by two different systems. The mentioned tariffs are multi-time and single-time tariffs. Three-time and multi-time electricity tariffs are determined by the Energy Market Regulatory Authority (EPDK). For calculating electricity prices, the unit price is calculated over $1 \mathrm{kWh}$.

The three-time multi-time tariff prices vary according to the three-time zones of the day [16]. Also, the mentioned three time zones are adjusted according to the electricity demand of the consumer. In countries with different summer and wintertime, the hours of the time zones expressed are certain, while the house in certain months change in countries will not be deferred. The unit price of electricity is higher when the electricity consumption of the users is high, and it is lower during the low hours. For example, because there is not much demand at night, the unit prices may decrease by half while in comparison to the evening hours while there is a lot of demand. In the decision of the Energy Market, Regulatory, Board dated December 2016; meters are read in a way that varies according to the application of summer. If the clock of the meters is changed according to the continuous summer application, consumption measurements will be made throughout the year according to the following time zones [17]. Tables 3 and 4 demonstrate the clock pattern of different periodic times in March and October.

Table 3. Clock pattern of the last Sunday in October and the last Sunday of March

\begin{tabular}{|c|c|}
\hline Clock patterns of October and Sunday \\
\hline Daytime Period & $07: 00-18: 00$ Hour \\
\hline Peak Period & $18: 00-23: 00$ Hour \\
\hline Night Period & $23: 00-07: 00$ Hours \\
\hline
\end{tabular}

Table 4. Clock pattern between the last Sunday in March and the last Sunday in October

\begin{tabular}{|c|c|}
\hline Clock pattern between the last Sunday in March and the last Sunday in October \\
\hline Daytime Period & $06: 00-17: 00$ Hours \\
\hline Peak Period & $17: 00-22: 00$ Hours \\
\hline Night Period & $22: 00-06: 00$ Hours \\
\hline
\end{tabular}

In the three-time tariff (multi-time tariff), the highest amount belongs to the peak period [18]. During the peak period, all people are generally at their homes. Devices with high electricity consumption, such as oven, washing machine, tea maker, dishwasher, and iron are used during peak hours [19]. When the demand is also high, the unit price of electricity is quite high compared to the night period, which the demands are so low. In Table 5 EPDK (Republic of Turkey energy market regulatory authority) reveals the statistics of the distribution system users in different fields. 
Table 5. EPDK (Republic Of Turkey Energy Market Regulatory Authority) prices between 01.10.2020 01.01 .2021

\begin{tabular}{|c|c|c|c|c|c|c|c|c|c|}
\hline $\begin{array}{l}\text { Distribution } \\
\text { system } \\
\text { users }\end{array}$ & $\begin{array}{l}\text { Single } \\
\text { Time } \\
\text { Retail } \\
\text { Energy } \\
\text { Fee }\end{array}$ & $\begin{array}{c}\text { Daytim } \\
\text { e Retail } \\
\text { Energy } \\
\text { Fee }\end{array}$ & $\begin{array}{c}\text { Peak Hour } \\
\text { Retail } \\
\text { energy } \\
\text { Fee }\end{array}$ & $\begin{array}{c}\text { Retail } \\
\text { Night } \\
\text { Time } \\
\text { Energy } \\
\text { Fee }\end{array}$ & $\begin{array}{l}\text { Distributi } \\
\text { on Fee }\end{array}$ & $\begin{array}{l}\text { Single } \\
\text { Time }\end{array}$ & $\begin{array}{l}\text { Day } \\
\text { Time }\end{array}$ & Peak & $\begin{array}{l}\text { Night } \\
\text { Time }\end{array}$ \\
\hline \multicolumn{5}{|c|}{ Medium Voltage } & \multicolumn{5}{|c|}{ Medium Voltage } \\
\hline \multicolumn{5}{|c|}{ Double Termed } & \multicolumn{5}{|c|}{ Double Termed } \\
\hline Industry & 52,3469 & 53,0581 & 87,0600 & 25,6153 & 9,3758 & 61,7227 & 62,4339 & 96,4358 & 34,9911 \\
\hline Business & 57,1457 & 57,7917 & 94,7940 & 28,3504 & 14,6119 & 71,7576 & 72,4036 & 109,4059 & 42,9623 \\
\hline Residence & 39,6655 & 40,4338 & 68,4152 & 18,0576 & 14,4731 & 54,1386 & 54,9069 & 82,8883 & 32,5307 \\
\hline $\begin{array}{l}\text { Agricultural } \\
\text { watering }\end{array}$ & 51,6935 & 52,2765 & 85,5525 & 25,6857 & 12,0340 & 63,7275 & 64,3105 & 97,5865 & 37,7197 \\
\hline Lightening & 52,3331 & & & & 14,0243 & 66,3574 & & & \\
\hline \multicolumn{5}{|c|}{ Single Termed } & \multicolumn{5}{|c|}{ Single Termed } \\
\hline Industry & 52,2106 & 52,9220 & 86,9239 & 25,4791 & 10,3564 & 62,5670 & 63,2784 & 97,2803 & 35,8355 \\
\hline Business & 57,5550 & 58,2010 & 95,2034 & 28,7596 & 18,2267 & 75,7817 & 76,4277 & 113,4301 & 46,9863 \\
\hline Residence & 39,3760 & 40,1443 & 68,1254 & 17,7679 & 17,8705 & 57,2465 & 58,0148 & 85,9959 & 35,6384 \\
\hline $\begin{array}{l}\text { Agricultural } \\
\text { watering }\end{array}$ & 51,9669 & 52,5499 & 85,8259 & 25,9588 & 14,9836 & 66,9505 & 67,5335 & 100,8095 & 40,9424 \\
\hline Lightening & 52,7130 & & & & 17,4942 & 70,2072 & & & \\
\hline \multirow{2}{*}{\multicolumn{5}{|c|}{$\begin{array}{l}\text { Low Voltage } \\
\text { Single Termed }\end{array}$}} & \multicolumn{5}{|c|}{ Low Voltage } \\
\hline & & & & & & & igle Term & & \\
\hline Industry & 53,4358 & 54,1469 & 88,1488 & 26,7042 & 16,0234 & 69,4592 & 70,1703 & 104,1722 & 42,7276 \\
\hline Business & 58,2674 & 58,9133 & 95,9156 & 29,4720 & 21,7152 & 79,9826 & 80,6285 & 117,6308 & 51,1872 \\
\hline Residence & 39,2701 & 40,0385 & 68,0197 & 17,6620 & 21,2381 & 60,5082 & 61,2766 & 89,2578 & 38,9001 \\
\hline $\begin{array}{l}\text { Martyrs' } \\
\text { families and } \\
\text { War } \\
\text { Veterans }\end{array}$ & 14,6019 & & & & 14,4043 & 29,0062 & & & \\
\hline $\begin{array}{l}\text { Agricultural } \\
\text { watering }\end{array}$ & 52,5506 & 54,0773 & 86,4098 & 26,5426 & 17,8429 & 70,3935 & 71,9202 & 104,2527 & 44,3855 \\
\hline Lightening & 53,3873 & & & & 20,7984 & 74,1857 & & & \\
\hline $\begin{array}{l}\text { General } \\
\text { Lightening }\end{array}$ & 29,6902 & & & & 20,7984 & 50,4886 & & & \\
\hline
\end{tabular}

Devices that are free to use with integration with the help of a remotely connected assistant before usage, will provide information and suggestions to the user on their screen. For example; a user who wants to run the dishwasher during the peak period will be able to suggest "you can start it after 22:00." However, by setting up an alarm system, the device will operate at the adjusted time. As a result, users will be able to follow their consumption values in terms of money and the costs, instantly or for use, and they will be made more conscious of savings.

\section{RESULTS}

As a result of the first study, it has been planned to integrate the RFID tag and tag reader supplied into the plug and socket produced with a three-dimensional printer (3D printer), to recognize the plug and to draw the consumption values. Subsequently, the consumption values of the devices were obtained from the products sold as "smart sockets" and calculations had applied. The RFID tag can cause heating in the smart plug socket system. For this reason, the recognition process can be provided by other technologies such as bar code and data matrix.

- Ensuring learning people about their electricity consumption transparently could be achieved in a more conscious community.

- The different electricity tariffs to improve the better services for users have been applied by the electricity supplier. 
- By integrating the planned card or software on the electronic devices, the user will be informed at that moment and more effective savings will be achieved.

Although the word saving is perceived as being thrifty, it has been understood that saving can be achieved by using some devices more wisely, and it has been determined that smart systems that can be alerted the consumers about this issue should be produced.

In this study, most of the electrical devices that can be used on-demand in a family with four members have been examined. The total consumption of electrical devices that can be used on-demand is the same as below;

- Iron 9\%,

- Washing machine 6\%,

- Vacuum cleaner 9\%,

- Dishwasher 23\%,

- Oven $19 \%$,

- Tea maker $10 \%$.

Also constituted the remaining $24 \%$ of others (Television, hairdryer, toaster, etc.). Users who use a multitime tariff will be able to save $25-30 \%$ by planning the use of appliances such as washing machines, dishwashers, and ovens only at night, without sacrificing their comfort.

\section{CONFLICTS OF INTEREST}

No conflict of interest was declared by the authors.

\section{REFERENCES}

[1] Başar, S., Tosun, B., and Bartik, A., "Türkiye'de Büyüme ve Sektörel Bazda Elektrik Tüketimi Arasındaki İlişki”, Atatürk Üniversitesi İktisadi Ve İdari Bilimler Dergisi, 34(3): 1089-1109, (2020).

[2] Pençe, İ., Kalkan, A., and Şişeci Çeşmeli, M., "Estimation of Turkey Industrial Electricity Consumption with Artificial Neural Networks for the 2017-2023 Period", Mehmet Akif Ersoy Üniversitesi Uygulamalı Bilimler Dergisi, 3(2): 206-228, (2020).

[3] Tansel, A., and Taşçı, H. M., "Hazard analysis of unemployment duration by gender in a developing country: The case of Turkey", Labour, 24(4): 501-530, (2010).

[4] Haliloğlu, E. Y., and Tutu, B. E., “Türkiye için kısa vadeli elektrik enerjisi talep tahmini”, Journal Of Yaşar University, 13(51): 243-255, (2018).

[5] Akbaş, E., "Milenyum çağının enerji problemi: elektrik sektörü çatışmaları”, Marmara Üniversitesi İktisadi ve İdari Bilimler Dergisi, 24(1): 81-103, (2015).

[6] Pala, B., Esen, G., "Türkiye'de ev tipi elektrikli cihazlarda enerji etiketi ve enerji verimliliği farkındalığı analizi”, Verimlilik Dergisi, (2), 81-97, (2018). Retrieved from https://dergipark.org.tr/en/pub/verimlilik/issue/36498/414228.

[7] Kama, Ö., and Kaplan, Z., "A proposal for improving energy efficiency in turkey: incentive pratices for white goods", Hukuk ve Iktisat Araştirmalari Dergisi, 4(1): 201-211, (2012).

[8] Demirsoy, G., "The Total Factor Productivity of Energy Efficiency in Buildings", Journal Of Polytechnic, 0900: 0-2, (2021). 
[9] Ghazal, M., Akmal, M., Iyanna, S., and Ghoudi, K., "Smart plugs: perceived usefulness and Satisfaction: evidence from United Arab Emirates", Renewable And Sustainable Energy Reviews, 55: 1248-1259, (2016).

[10] Kırbaş, İ., "Energy Efficiency Applications in Buildings: The Sample of the MAKU Engineering And Architecture Faculty, Burdur-Turkey", Mehmet Akif Ersoy Üniversitesi Fen Bilimleri Enstitüsü Dergisi, 10(2): 141-149, (2019).

[11] Deng, F., Wen, K., Zeng, H., and Xie, Z., "Novel metal-oxide arrester monitoring technology based on RFID sensor and mind evolutionary computation", Electric Power Systems Research, 192: 106859, (2021).

[12] Yumurtacı, Z., and Dönmez, A. H., "Konutlarda Enerji Verimliliği”, Mühendis ve Makina Dergisi, 637(54): 38-43, (2013).

[13] Brounen, D., Kok, N., and Quigley, J. M., "Energy literacy, awareness, and conservation behavior of residential households", Energy Economics, 38: 42-50, (2013).

[14] Bilgen, S., "Structure and environmental impact of global energy consumption", Renewable and Sustainable Energy Reviews, 38: 890-902, (2014).

[15] Brounen, D., Kok, N., and Quigley, J. M., "Residential energy use and conservation: Economics and demographics", European Economic Review, 56(5): 931-945, (2012).

[16] Muratori, M., and Rizzoni, G., "Residential demand response: Dynamic energy management and timevarying electricity pricing”, IEEE Transactions On Power Systems, 31(2): 1108-1117, (2015).

[17] Hill, S. I., Desobry, F., Garnsey, E. W., and Chong, Y. F., "The impact on energy consumption of Daylight saving clock changes", Energy Policy, 38(9): 4955-4965, (2010).

[18] Paterakis, N. G., Erdinc, O., Bakirtzis, A. G., and Catalão, J. P. S., "Optimal household appliances Scheduling under day-ahead pricing and load-shaping demand response strategies", IEEE Transactions On Industrial Informatics, 11(6): 1509-1519, (2015).

[19] Damigos, D., Kontogianni, A., Tourkolias, C., and Skourtos, M., "Behind the scenes: Why are energy efficient home appliances such a hard sell?" Resources, Conservation and Recycling, 158: 104761, (2020). 